\title{
Impact of COVID-19 lockdown on small-scale fishers (SSF) engaged in floodplain wetland fisheries: evidences from three states in India
}

\author{
Basanta Kumar Das ${ }^{1} \cdot$ Aparna Roy $^{1}$. Sukanya Som ${ }^{1} \cdot$ Ganesh Chandra $^{1} \cdot$ Suman Kumari ${ }^{1} \cdot$ Uttam Kumar Sarkar $^{1}$. \\ Birendra Kumar Bhattacharjya ${ }^{1} \cdot$ Archan Kanti Das $^{1} \cdot$ Arun Pandit $^{1}$
}

Received: 28 May 2021 / Accepted: 17 August 2021 / Published online: 6 September 2021

(C) The Author(s), under exclusive licence to Springer-Verlag GmbH Germany, part of Springer Nature 2021

\begin{abstract}
The COVID-19 pandemic has created unprecedented human health crisis in recent global history with rippling social and economic effects. The outbreak in India has resulted in emergency lockdown in the country for more than 2 months, and that caused decline in the catch, demand, and supply of fish. It has severely altered the life and livelihoods of the floodplain wetland fishers. These floodplain wetlands play a key role in socio-economic development of stakeholders, by generating employment and livelihood in the studied regions. In the present study, a systematic assessment was conducted to identify the impact of lockdown on floodplain wetland fisheries in India with the aim to evaluate the impact of the COVID-19 lockdown on wetland fishing, fisheries production, income, and food access. We conducted a rapid telephonic survey covering 176 wetland fishers in 3 states to document the early impacts of the pandemic and policy responses on floodplain wetland fisher households. The majority of fishers report negative impacts on production, sales, and incomes. Fishers of three Indian states Bihar, West Bengal, and Assam lost 20, 25, and 9 fishing days, respectively. About 70, 60, and $55 \%$ fishers of floodplain wetlands of the three states admitted that lockdown made them partially jobless. Fish harvest during March to May was 32, 44, and $20 \%$ lower than the previous years in Bihar, West Bengal, and Assam. The fishers of Bihar, West Bengal, and Assam lost income of INR 10000/-, 12500/-, and 4500/- due to lockdown. The analysis also showed that $25 \%$ of fishers each responded moderate to severe psychological impact and anxiety symptoms due to COVID-19. Demand supply gap during the lockdown led to the in 20-40 $\%$ increase in farm gate price of fishes at the wetland level. The present study is the first of its kind in India to systematically assess the impact and discusses several magnitudes on floodplain wetland fisher livelihood, income, and food access and suggests strategies and decision support.
\end{abstract}

Keywords COVID-19 · Lockdown · Floodplain wetland · Impact · Inland fisheries $\cdot$ Income $\cdot$ Food security

\section{Introduction}

The COVID-19 pandemic has created unprecedented human health crisis in recent global history with rippling social and economic effects (Bennett et al. 2021; Everard et al. 2020; Hakovirta and Denuwara 2020). This coronavirus 2 (SARS-CoV-2) was first recorded in Wuhan City in Hubei Province, People's Republic of China, in December 2019

Responsible editor: Baojing Gu

Basanta Kumar Das

basantakumard@gmail.com

1 ICAR-Central Inland Fisheries Research Institute, Monirampur, Barrackpore, Kolkata 700120, India
(Wang et al. 2020) and reported to the World Health Organization (WHO) on 31 December 2019 (WHO 2020). To control the spread of COVID-19, mobility restriction in the form of lockdown set in place in early 2020 disrupted economies worldwide and affecting population vulnerable to poverty and malnutrition (Laborde et al. 2020). As on 1 January 2021, 81.9 million cases of SARS-CoV-2 have been reported in 222 countries across the globe with death toll that stands at 1,808,041. The Asian Development Bank has assessed the potential economic impact of the COVID-19 outbreak on Asian economies across various scenarios and suggested a global impact of $\$ 77$ billion to $\$ 347$ billion or 0.1 to $0.4 \%$ of global GDP (gross domestic product), with a moderate case estimate of $\$ 156$ billion or $0.2 \%$ of global GDP (ADB 2020).

With the high population density and inadequate health infrastructure, the potential of large, quick, and deadly 
outbreak prompted early response from the federal government in the form of national lockdown. The Prime Minister of India declared nationwide complete lockdown since 24 March 2020; during this period, restriction imposed on the commercial and industrial activity coupled with ban on the movement of people and goods was deemed non-essential in nature as a preventive measure against the COVID-19 pandemic in India. These lockdown measures were anticipated to safeguard the public health and, however, have a direct and distressing impact on income and food security, predominantly for the susceptible subsistence segment in rural India. Complete lockdown of all economic activities created an immediate economic crisis leading to extreme hardship and rising food insecurity. This unprecedented lockdown measures have resulted in adverse impacts on employment, income, food, and nutrition security of the fishers and the potential to cause social unrest. The SSF are in fact characterized by high level of risks and uncertainty and COVID-19 lockdown, a shock that accelerate the uncertainty and leads the vulnerability of the poor fishers. The FAO define SSF as encompassing wide-ranging activities undertaken throughout the value chain by both men and women in inland and marine fisheries, including harvesting from boats and on foot, along with pre- and post-harvest labor that occurs on land (FAO 2015). The several reports indicate that inland SSF likely provide even more jobs than their marine counterparts (56 versus 52 million) and play an especially important role in local nutrition and food security (World Bank 2012; Bennett et al. 2018; Funge-Smith 2018; Jena and George 2018). The composition of the SSF workforce is also more diverse than previously thought, with women representing nearly half of SSF workers globally (World Bank 2012; Smith and Basurto 2019). The inland fisheries sector in India especially floodplain wetlands are dominated by SSF mostly belonging to fisherman community (Chandra and Ekka 2015).

Worldwide, SSF is responsible for sustainable livelihoods of more than 120 million people, $95 \%$ of them belong to developing countries (FAO 2000). The outbreak of COVID-19 pandemic in India has called for sudden strict and prolonged lockdown in the country for more than 2 months that caused adverse impact on the SSF, fish demand and supply, and value chain disruptions in the fishery sector. It has put the Indian marine sector in a deep sea imposing a daily loss of INR 224 crore, and monthly loss was estimated at INR 6838 crore (Aqua International 2020). The inland fishery sector of India is dynamic in nature, which produces more than 8.4 million tonnes including culture and capture fisheries and contributes more than $65 \%$ of total fish production during 2018-2019 (Handbook on Fisheries Statistics 2018). The Food and Agriculture Organization of the United Nations (FAO) reported 11.9 million tonnes of global inland fishery catch, representing 12.7 percent of total global capture fisheries (FAO, 2019). Worldwide, inland fisheries contribute a significant role in food and nutritional security, poverty alleviation, gender empowerment, socio-economic development of small and marginal fishers, ecosystem services, and biodiversity conservation (Funge-Smith and Bennett 2019; Zhang et al. 2020). As per Livestock Census 2003, the total inland and marine fisherman population in India was $14,485,354$ which includes 4,696,158 males, 4,033,963 females, and 5,755,233 children, contributing to 1.1 percent of the Indian GDP (Handbook on Fisheries Statistics 2014). The floodplain wetlands are one of the prime fishery resources of India having 525,028 ha water area and high production potential to the tune of 2000-2500 $\mathrm{kgha}^{-1} \mathrm{yr}^{-1}$ (Chandra and Das 2019; Sugunan and Sinha 2001; Sarkar et al. 2019; Sarkar et al. 2020). The average fish production from these water bodies is $230 \mathrm{kgha}^{-1} \mathrm{yr}^{-1}$ (Chandra et al. 2013). Bihar has the highest area under floodplain wetlands (209,000 ha) followed by Uttar Pradesh (153,000), Assam (100,872 ha), West Bengal (42,500 ha), and Manipur (16,500 ha) (Chandra and Das 2019; Sarkar et al. 2020). These wetlands (locally known as beel/baor in West Bengal, maun or chaur in Bihar, beel in Assam) are the one of the prime SSF resources of eastern and north-eastern India (Sugunan and Bhattacharjya 2000), providing livelihood and nutritional support to a large section of the population next only to agriculture (Chandra 2010; Chandra and Das 2019). These invaluable resources are managed for various objectives like economic benefit, livelihood security, sustainability, equity, conservation of biodiversity, and maintenance of the ecosystem (Chandra 2009; Chandra and Bhattacharjya 2016; Sarkar et al. 2020). Scientific management along with good governance and adoption of technological interventions can double the production of these wetlands (Sarkar et al. 2020). Over the years, management guidelines for development of floodplain wetland fisheries were time to time issued by ICAR-CIFRI (Sugunan and Sinha 1997, Sugunan and Bhattacharjya 2000, Sugunan and Bhattacharjya 2000, Sugunan et al. 2002, Das et al. 2019).

These lockdown measures were implemented during the medium intensity harvesting season of March to April. Although the policy response to COVID-19 outbreak was largely coordinated by the federal government, states adopted additional restrictive and relief measures with different levels of enforcement and monitoring, resulting in diverse lockdown environment and may have given rise to a large number of heterogeneity in the COVID-19 response on fishery activity and consumption (Ceballos et al. 2020). During this pandemic, majority of attention was on the human health front, but there have been numerous reports on the impact of the pandemic on different sectors including agriculture and fisheries. Although several studies related to agricultural production, livelihoods, and food security during the COVID-19 lockdown in India have recently been reported (Acharya 2020; 
Azim Premji University 2020; Ceballos et al. 2020; Harris et al. 2020; Jaacks et al. 2021), the impact and analysis of the inland SSF sector have not been studied so far. Studies on SSF were mainly focused on the marine and coastal fishery sectors (Bennett et al. 2021, Briceno-Lagos and Monfort 2020, FAO 2020, Mangubhai et al. 2021; Stokes et al. 2020). In a recent report, Coll et al. (2021) have studied ecological and economic impact of COVID-19 on marine small-scale and commercial fisheries, but due to short-term impact of lockdown/restriction fishing, no impact on ecosystem was detectable. Gretchen et al. (2020) have online-based survey in 79 countries, which found positive impact of COVID-19 on environmental health and higher risk on livelihood and nutritional security of inland fishers and dependent. Keeping the importance of small-scale inland fishery sector, we analyzed disruption of COVID-19 to fishery incomes and food security in wetland fishery sector in India.

To contribute to the understanding of the effects of COVID-19 responses on small-scale floodplain wetland fishers, in this communication, we present results from primary phone-based survey covering 176 wetland fishers in three wetland-dominated states (West Bengal, Bihar, and Assam). These surveys were complemented by key informant interviews to provide insight on how fishers' livelihood were disrupted and how they responded to these challenges imposed due to lockdown restriction. We also attempt to bring out immediate impacts on wetland fisheries in India and suggest effective management strategies, decisions, and institutional responses to mitigate the threats.

\section{Methodology}

\section{Study area}

Three states are namely West Bengal $\left(22.9868^{\circ} \mathrm{N}, 87.8550^{\circ}\right.$ E), Bihar $\left(25.0961^{\circ} \mathrm{N}, 85.3131^{\circ} \mathrm{E}\right)$ of Ganga River system, and Assam $\left(26.2006^{\circ} \mathrm{N}, 92.9376^{\circ} \mathrm{E}\right)$ of Brahmaputra River system, Eastern India. Floodplain wetlands are one-third of the area of fishery resources of these states. Five floodplain wetlands from each of the states were selected under this study (Table 1). The cooperative-based management regime governs the wetland fisheries in West Bengal and Bihar (Chandra and Ekka 2015; Chandra and Das 2019; Sarkar et al. 2020); hence, all five wetlands of these two states were cooperatively managed. In Assam both cooperative and individual management regimes are operational (Chandra 2009, 2011); hence, three individual and two cooperative managed wetlands were selected from Assam. The location of the study area has been presented in Fig. 1.

\section{Sampling design}

The first nationwide lockdown phase one was clamped for 21 days from 24 March 2020 to 14 April 2020. This lockdown was further extended for 19 days as phase two until 3 May 2020 and then further for 14 days until May 17 as phase three to stop the spread of COVID-19. However, many states including West Bengal extended to 31 May 2020. In this contributions, phase three included the period up to 31 May 2020.

Table 1: Basic information of the study sites in three different states of India

\begin{tabular}{|c|c|c|c|c|c|c|c|}
\hline Sl. No. & Name of the state & Wetland & $\begin{array}{l}\text { Management (individual/ } \\
\text { cooperative/open access) }\end{array}$ & $\begin{array}{l}\text { Area } \\
\text { (ha) }\end{array}$ & $\begin{array}{l}\text { Number } \\
\text { of members }\end{array}$ & $\begin{array}{l}\text { Yield of carps } \\
\text { (tonnes/ha/ } \\
\text { year) }\end{array}$ & $\begin{array}{l}\text { Number of } \\
\text { respondents interviewed }\end{array}$ \\
\hline 1 & \multirow[t]{5}{*}{ West Bengal } & Chamardaha & Cooperative Management & 38.85 & 147 & 0.55 & 15 \\
\hline 2 & & Beledanga & Cooperative Management & 60 & 176 & 0.53 & 15 \\
\hline 3 & & Panchita & Cooperative Management & 47.39 & 237 & 0.74 & 15 \\
\hline 4 & & Akaipur & Cooperative Management & 32 & 80 & 0.60 & 10 \\
\hline 5 & & Kholsi & Cooperative Management & 62 & 151 & 0.53 & 15 \\
\hline 6 & \multirow[t]{5}{*}{ Bihar } & Karariya & Cooperative Management & 120 & 120 & 0.55 & 15 \\
\hline 7 & & Rulhi & Cooperative Management & 80 & 90 & 0.15 & 15 \\
\hline 8 & & Sirsa & Cooperative Management & 82 & 125 & 0.32 & 15 \\
\hline 9 & & Kothiya & Cooperative Management & 80 & 230 & 0.27 & 15 \\
\hline 10 & & Majhariya & Cooperative Management & 120 & 120 & 0.2 & 15 \\
\hline 11 & \multirow[t]{5}{*}{ Assam } & Rupahi & Individual Lessee Managed & 75 & 30 & 0.4 & 3 \\
\hline 12 & & Garudharia & Cooperative Management & 32 & 25 & 0.2 & 5 \\
\hline 13 & & Borghuli & Individual Lessee Managed & 21 & 20 & 0.55 & 3 \\
\hline 14 & & Borbila & Cooperative Management & 55 & 200 & 0.3 & 15 \\
\hline 15 & & Warigendeng-Kenduguri & Individual Lessee Managed & 40 & 35 & 0.4 & 5 \\
\hline
\end{tabular}


Fig. 1 Map showing details of the study area

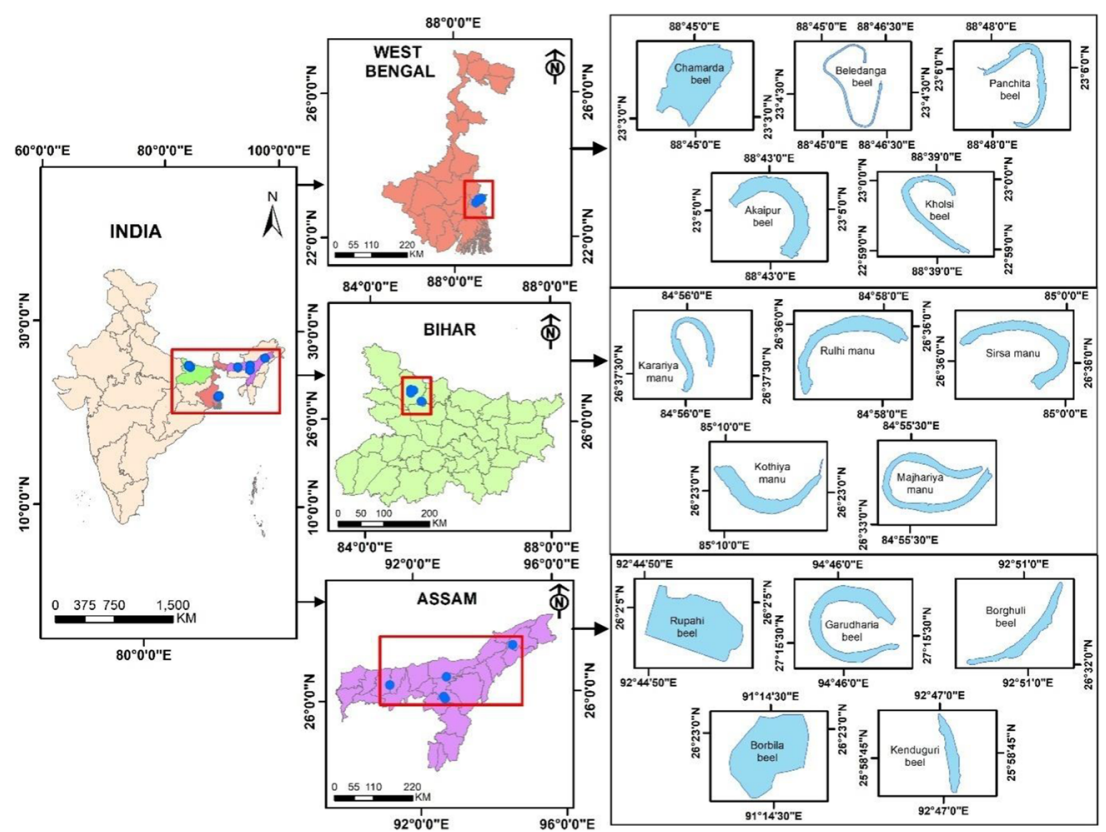

We conducted rapid assessment using semi-structured interview with questions including socio-economic and socio-psychological variables. We collected primary data through phone survey on wetland fishery operation undertaken between the months of March to May. We aimed to survey sample representative of wetland fishers of Assam, West Bengal, and Bihar. Following the survey, key informant interviews (KIIs) were conducted with nine managers (lessees in the individual managed wetlands and secretary of fisheries cooperative society for cooperative managed wetlands) from three wetlands each from Assam, West Bengal, and Bihar to understand the context and implementation of regulation in the studied location. One hundred seventy-six fishers having mobile phones were purposively selected for this study (Table 1), and data were collected through direct conversation with the stakeholders. We conducted the interviews on three occasions, first week of April, second week of May, and second week of October 2020 over telephone to comply with the restriction imposed on movement within states and interstate in India and COVID-19 guidelines issued by respective state government. Telephonic interviews were restricted to limited numbers of questions to ascertain the impact of lockdown and fishers' response to mitigate the problem. The phone survey was conducted in the fishers' primary language (Bengali in West Bengal, Hindi in Bihar, and Assamese in Assam) and included questions on how wetland fishery operations were affected by the lockdown. We asked questions focused on stresses faced by the fishers. The survey also included question on access to food during the lockdown and month before the lockdown. The use of mobile phones/telephones as a method for conducting interviews has a number of benefits, such as cost-effectiveness, time efficiency, and access to individual, and it is now gradually becoming more popular data collection means (Cooper and Kurland 2002, Polkinghorne 2005, Schweitzer and Duxbury 2006, Ilies et al. 2007). Studies conducted by using semi-structured interview methods through telephonic dialogue have gathered equally robust information with respect to breadth and depth (Block and Erskine 2012). Within the studied states, restrictions continued even after relaxations were announced in pockets depending on the status of the locality in terms of severity of contamination. Therefore, the last interviews with key informants were conducted in the month of October to comprehend the situation in the lockdown period with the normal period. The impact of lockdown during COVID-19 on environmental factor and pollution was discussed based on secondary available literature.

\section{Data analysis}

We extracted data for qualitative and quantitative analysis by hand transcribing audio data from telephone interviews. We triangulated the data and results with key informant interviews to determine how much of the observed changes were likely due to COVID-19 or to other reasons.

\section{Results}

The floodplain wetlands of Bihar, Assam, and West Bengal, India, are under the ownership of different government departments. In Bihar and West Bengal, these waterbodies were leased to fisherman cooperative society for fishery management (Chandra and Ekka 2015; Sarkar et al. 2020; Chandra 
and Das 2019), while in Assam, the waterbodies are leased to either individual fishers or fisherman cooperative society (Chandra 2009, 2011, Chandra and Das 2019). Fishery management practices also differ in these states (Chandra 2010; Chandra et al. 2013; Sarkar et al. 2020). The COVID-19 impact on the wetland fishers shows visible changes in various activities related to fisheries. The fisher responses to the lockdown were different in all three states. The result is presented in three broad themes that emerged from the survey, namely impacts on wetland fishery livelihood, income, and food access. These themes are also disaggregated based on the respondents' engagement.

\section{Impact on wetland fisheries}

\section{Fishing days}

All the fishers (100\%) responded that they were not allowed to fish in first phase due to strict lockdown enforced by the local authorities. In second phase, fishers of Bihar, West Bengal, and Assam responded 73, 56, and $30 \%$ loss in fishing days, respectively. There was 53 and $42 \%$ loss of fishing days in West Bengal and Bihar, respectively. Fishing ban was observed from 20 April to 15 June; hence, no loss was reported from third phase in Assam (Fig. 2). The sudden lockdown falls during the medium intensity period of fishing in wetlands of Bihar, Assam, and West Bengal led to a significant economic loss to fishers because of loss of fishing days. In Bihar local administration allowed fishers to do fishing and sell for $4 \mathrm{~h}$ in the morning in the second phase. In third phase of lockdown, this restriction was lifted by the district administration leading to normalcy in the fishing operation. In West Bengal, though fishing is partially allowed in second phase of lockdown, most of fishers could not do fishing due to supply-side constraints. The fishers of Bihar, West Bengal, and Assam lost 20,25, and 9 fishing days, respectively, due to lockdown. Overall, one fishing day provides an average income of INR 500 to wetland fisher.

\section{Fish catch/fishing practices}

To further quantify the impact of COVID-19 lockdown on wetland fishers' livelihood, we asked the fishers if they were (a) fishing same amount of fish and (b) fishing in group as like previous year. When asked more directly about fish harvest, majority of fishers $(68 \%)$ stated that the fish catch was less than the last year. Fishers of Bihar, West Bengal, and Assam responded that the fish harvest during March to May was 32, 44 , and $20 \%$ lower respectively than the previous year due to lockdown restriction. Explanations for the reduced fish catch include reduction in fishing days, restrictions on group fishing due to COVID-19 measures, and time allowed for harvesting operation. The group fishing is a community-based practice in wetland fisheries in all three states, but due to COVID-19 measures, numbers of fishers fishing in wetlands were restricted. Fishers of West Bengal stated that due to restriction on group fishing, the harvesting operation was delayed. Fishers of Bihar stated that in earlier years, during this period, fish harvesting was done on alternate days with $300 \mathrm{~kg}$ catch per fishing day. The fish harvesting during lockdown was initiated after 15 April 2020 keeping with the COVID advisory by maintaining $2 \mathrm{~m}$ of physical distance with covering of the face. The distance between two boats was maintained at $6 \mathrm{~m}$ apart. Due to the loss of 20 fishing days in the month of March to April and reduced intensity of fishing after 15 April onwards, fishers estimated a loss of about $32 \%$.
Fig. 2 Percentage loss of employment to fishers during different phases of lockdown

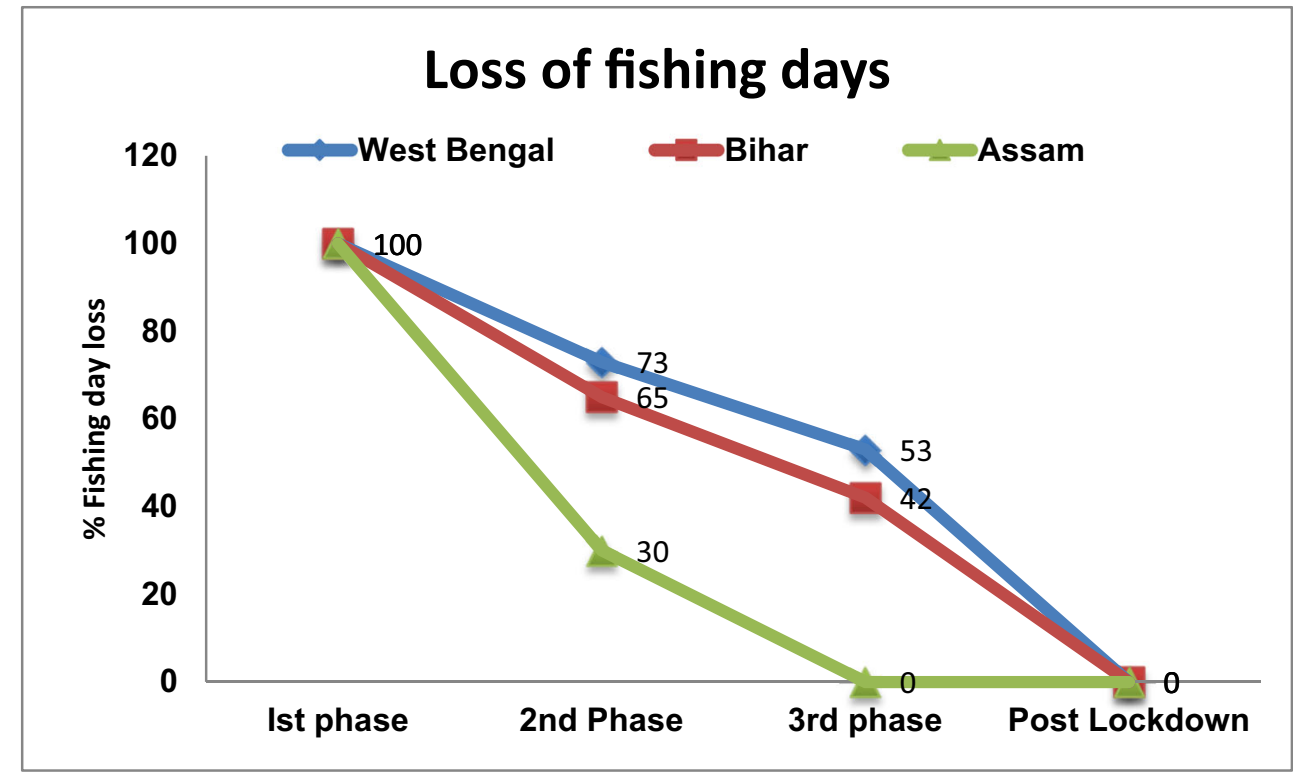




\section{Marketing/fish value chain}

Three kinds of value chains were operational in wetland fisheries prior to lockdown in all the three states: (a) fishers-retailers-consumers, (b) fishers-landing centers-whole sellers-retailers-consumers, and (c) fishers-consumers.

Supply-side constraint mainly mobility restriction and closure of transport led to disruption of fish value chain. During lockdown restrictions, the broadly operated value chain involving fishers-whole sellers-retailers-consumers was completely wanting. In Bihar after the relaxations in phase II, all harvested fish were directly purchased by the retailers from fishers at farm gate level in the morning hours due to restricted fish sale time from 8 to 10 AM. The other impact of lockdown was visible in increase in price of fish in market due to huge demand supply gap. The fish supply of fish was half of normal times in the market, and this demand supply gap led to $20-40 \%$ increase in farm gate price of carps and catfishes in Bihar, West Bengal, and Assam. Approximately $15 \%$ of fish demand of Assam is met from other states of the country. Due to transport restriction, fish supply from other states has completely stopped, and this led to the increase of fish price by 25-40\% higher than the period before lockdown. In West Bengal, cooperative societies (PFCS) of the selected wetlands decided not to harvest the fish because of very low options of selling the harvested fish to the whole sellers.

\section{Impact on income}

The sudden lockdown and restriction of fishing in wetlands led to considerable loss of income to the fishers. In total, 70, 60 , and $55 \%$ of the respondent fishers of wetlands of West Bengal, Bihar, and Assam admitted that the lockdown made them partially jobless. Due to loss of fishing days, fishers of Assam, West Bengal, and Bihar lost income of 70, 56, and 60 in the first phase of lockdown and 30,44 , and $40 \%$ in second and third phases of lockdown (Fig. 3). The income loss to each fisher due to lockdown was INR 10000/-, 12500/-, and 4500/-, respectively, in Bihar, West Bengal, and Assam and on an average INR 9000 for an Indian wetland fisher.

Perceived economic loss by Fishermen Cooperative Societies (FCSs) of Bihar and West Bengal during the COVID-19 lockdown period has been presented in Fig. 4. All the respondents of West Bengal reported decrease in fish consumption due to high demand and less supply of fish in the market raising its price.

\section{Food access}

Disruption of agriculture sector as a whole including inland fisheries and income losses has also affected fishers as a consumer. During the phone survey, we asked the respondents on (a) household affordability of sufficient quantity of food and (b) affordability of sufficient variety of food (including grain, pulse, fish/egg, vegetables) to assess the potential impact of lockdown on the fishers household. We found that around 70 $\%$ of the households were affording more or less same quantity of food during the lockdown period. They said that they have used household saving for purchase of food materials. Only 45, 52, and 40 percent of fishers of Assam, West Bengal, and Bihar responded that they afforded more or less sufficient variety of food as like before lockdown period. Almost all the respondents of West Bengal reported that there was a decrease in fish consumption due to high demand and less supply of fish in the market raising its price. According to them, $75 \%$ of people did not consume fish or consumed fish occasionally
Fig. 3 Income loss by individual fishers during different phases of lockdown

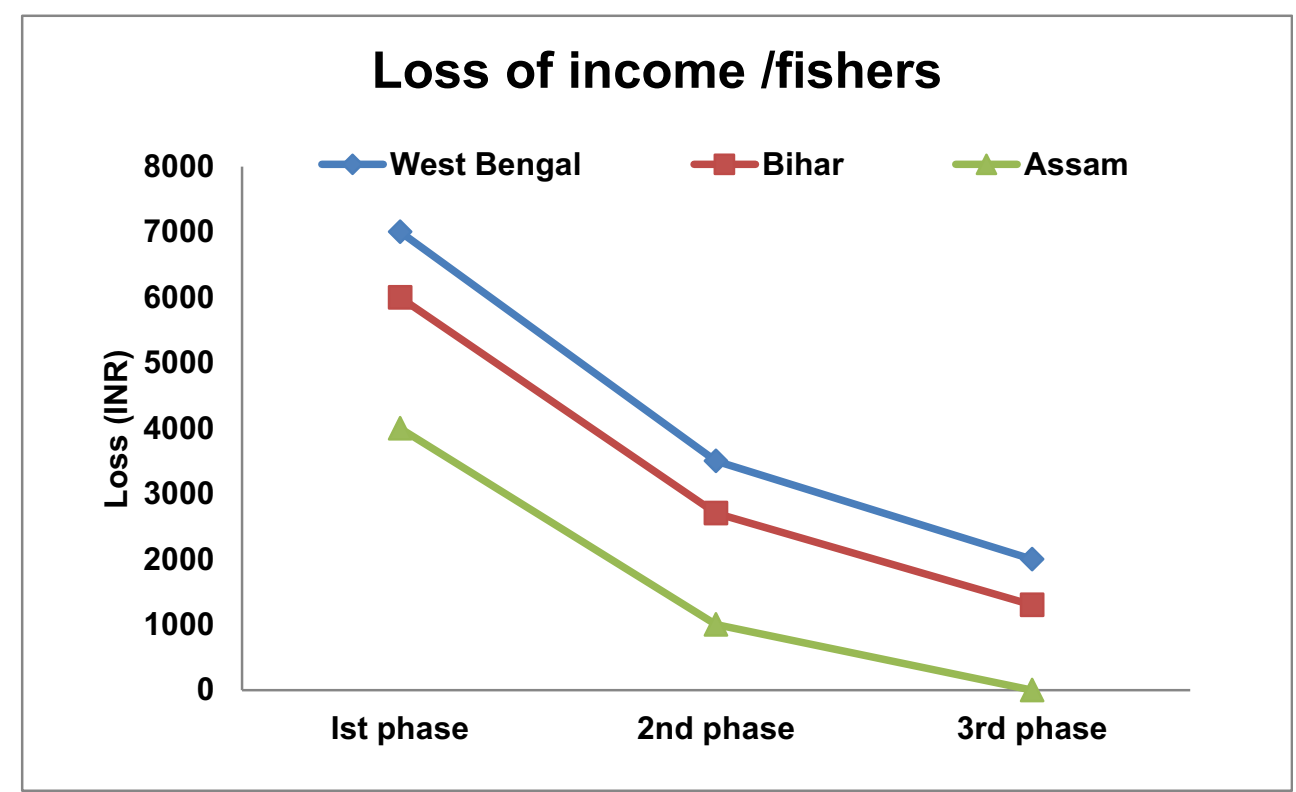


Perceived Economic Loss of the FCS due to Covid-19 Lockdown

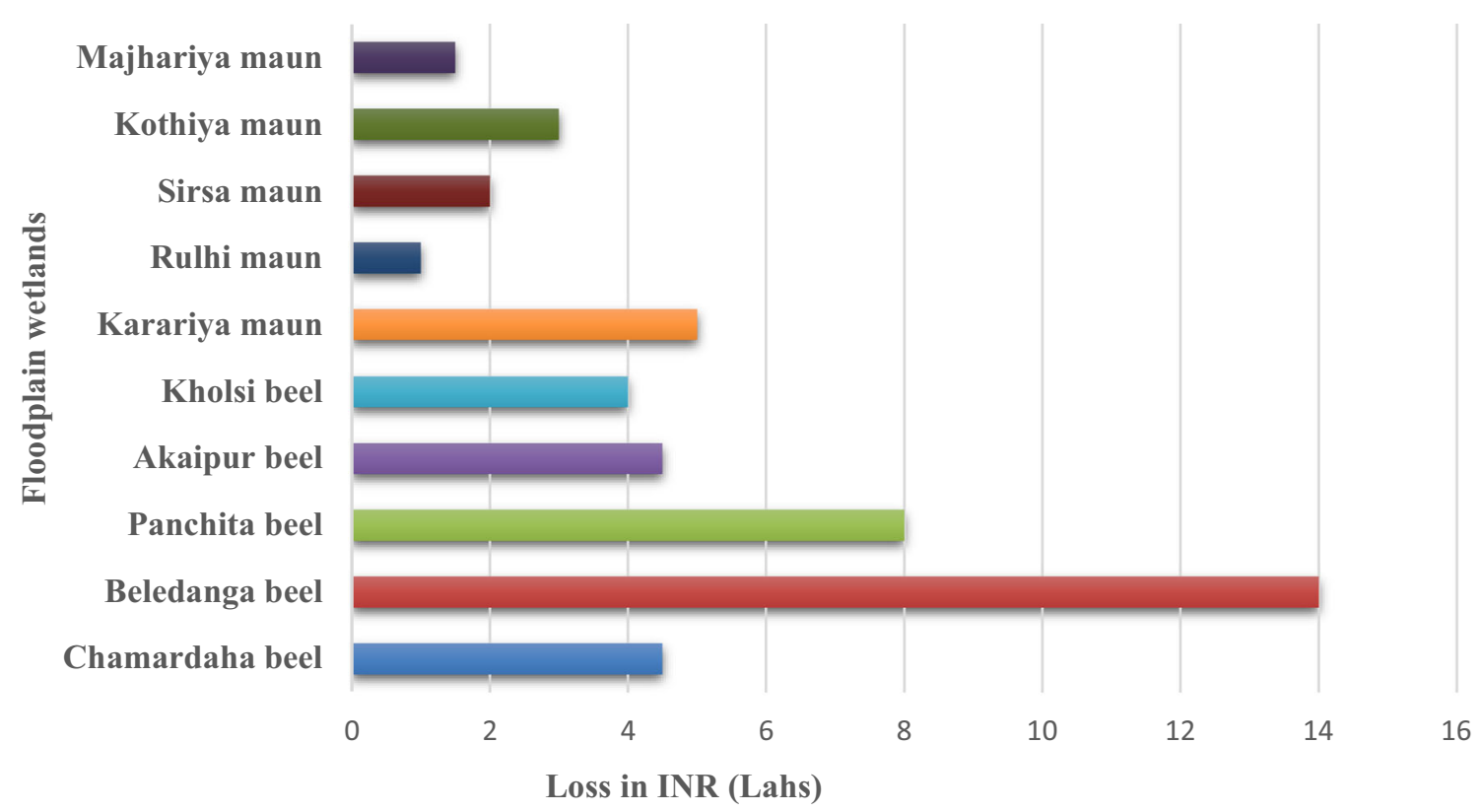

Fig. 4 Perceived economic loss by Fishermen Cooperative Societies (FCSs) during the COVID-19 lockdown period

during lockdown. In comparison to West Bengal, fish consumption by fishers by Assam and Bihar were slightly better. The lack of income during the lockdown probably caused insufficiency in the nutritional needs of the fishers' families in all the three states.

The Federal Government of India announced under the Pradhan Mantri Garib Kalyan Yojana (PMGKY) that $5 \mathrm{~kg}$ food grains and $1 \mathrm{~kg}$ pulses per persons of each household below the poverty line are provided free of cost through the public distribution system for the month of April to September. PMGKY provided the necessary safety net to the poor population during this lockdown (Mahendra 2020).

\section{Other stress}

Due to lockdown, households have faced different kind of stresses like financial, mental and physical, and social stress. The fishers were anxious, constantly under stress, and faced difficulty for not being able to socialize. Concerning their physio-psychological changes due to restriction on social gathering created a feeling of occasional isolation and sadness among them. Twenty-five percent of respondents rated the psychological impact of the COVID-19 outbreak as moderate to severe; 25 percent of the fishers reported moderate to severe anxiety symptoms. Most fishers reported that they are spending more than $17 \mathrm{~h}$ per day at home.

One phenomenon seen in all the states was that fishers were comparatively less anxious about the financial loss as they believed they would be able to recover the loss after the opening of the lockdown. The price of fish has been appreciated by
$25-40 \%$ due to supply-side constraints. The fishers are anticipating that they will recover partial loss due to high price realization. The most contrasting case was of Kothia wetland in Bihar, where harvest was allowed only in third phase of lockdown after 12 May 2020. Harvesting was carried out for next 10 days and 5 metric tons of fish harvested, providing a good earning to the fisher community.

\section{Institutional response to support fishers}

Institutional response to support fishers varied in different states. In Bihar the response was timely. Department of fisheries notified fisheries as essential activity and instructed the district administration to allow fishery activities in water bodies. Fishing was allowed from 5 to $10 \mathrm{AM}$ in the morning by the district administration from 15 April 2020. This timing was further relaxed from 25 April 2020.

Government of India and state governments have announced several measures to help the public to cope hardship during the lockdown period. This includes announcement of fisheries as a part of essential activity and allowing fishers to do fishing operation during lockdown period maintaining COVID-19 social distancing protocol. Government of India announced \$22 billion relief package which include food and cash transfers for the poor. This includes INR 2000 cash transfers to the bank accounts of 87 million farmers under PM Kisan scheme (Dhakade 2000). The daily wages under MNREGS was increased from INR 182 to 202; apart from it, LPG gas used in cooking food was provided 
free of cost by the Government of India under Ujjawala Yojana to below poverty line households. All these measures have helped fishers during this COVID-19 pandemic.

\section{Discussion}

The unprecedented havoc created by COVID-19 virus worldwide prompted many countries in the world including India to rapidly respond with measures to stop the spread of coronavirus and save the human life. For rich and poor countries alike, the coronavirus pandemic and the associated policy responses brought a widespread health calamity, economic hardship, severe disruptions to services, and previously unimaginable restrictions on movement. Many poor and vulnerable people have faced serious threats to their immediate food security, health, and nutrition (IFPRI 2021). The pandemic's impacts on food security have been induced primarily by falling incomes. The World Bank estimates that the global economy shrank by 5 percent in 2020, with the greatest burden borne by poor people. Food supply chains were disrupted by labor restrictions and falling demand, although impacts varied along the value chains.

The swift announcement of lockdown and closure of intra state and state borders has averted the catastrophic health crisis. The inland fisheries including wetland fisheries have not been immune to global health crisis (Bennett et al. 2021). The review of literature shows very few reports about the crisis faced by fisheries sector due to COVID-19 pandemic (Eriksson et al. 2020, Steenbergen et al. 2020, Aura et al. 2020, Campbell et al. 2021, Mangubhai et al. 2021, Love et al. 2021). This study identified the impact of COVID-19 lockdown on floodplain wetland fisheries in India and discussed comprehensively the impact on the livelihood, income, and food access of the wetland fishers.

Wetland fisheries of studied states include fish catch of both self-recruiting fish and stocked fish. In India, fisheries fall under the state jurisdiction with each state having its own policy and strategy for fishery development (DebRoy et al. 2021). There are similarities in fish catch of self-recruiting fish of high-demand species such as Clarias batrachus (Climbing catfish, mangur), Heteropneustes fossilis (Stinging catfish, Singhi), Anabas testudineus (climbing perch), Channa striatus (striped snakehead), C. marulius (bullseye snakehead), Macrognathus armatus (Spiny eel), M. aral (one-stripe spiny eel), Puntius sophore, P. ticto, Mystus tengara (Tengara), M. cavasius (Singarah), and Gudusia chapra (Indian river shad) and stocked fish species such as Indian Major Carps (Labeo catla, Labeo rohita, and Cirrhinus mrigala) (Kar 2019; Hassan et al. 2019). These species are the major SSF of the studied three states.
The prolonged lockdown has a direct impact on both the life and livelihoods of the wetland fishers, since fish harvest was stopped in most of the wetlands. In West Bengal, it was due to supply-side disruptions, while in other two states, it was due to restriction of fishing completely. Because of this, the household income has suddenly gone down and forced fishers to do wage earning to support their family nutritional needs. Interestingly, fishers of different states responded differently to the crisis. Fishers of Bihar were able to harvest fish from 15 April 2020 and sell their produce. Fishers of West Bengal were facing supply-side problems in sale of their produce; with the issuance of movement pass, they overcome this problem. Assam fishers were most worried about the impending ban on fisheries from 15 April 2020. The Government of Assam allowed fishing until 20 April 2020, and this helped fishers to harvest fish. The livelihood loss incurred due to sudden lockdown may have a prolonged economic impact on the floodplain wetland fishers.

A speedy recovery is very much intended, and it could only be possible if cooperation between state fishery department and the fishers of respective wetlands shall be encouraged. This will also help the wetland fishers in getting medium and long-term support from the institutions. In order to protect the livelihood security of the wetland fishing communities, an instantaneous assistance package may be rolled out. The Mahatma Gandhi National Rural Employment Guarantee Act 2005 (MGNREGS) schemes shall also include wetland macrophyte cleaning, fish feeding, and pen installation as skilled jobs and may be paid under the same scheme. Inland fisheries are an indispensable part of healthy aquatic ecosystems. The floodplain wetlands of India are productive ecologically as well as economically and provides huge amount of goods and services to the population inhabit along the wetland ecosystem (Sarkar and Borah 2018; Das et al. 2019; Sarkar et al. 2020). In spite of the wetland being a most productive ecosystem for fisheries and livelihood support, the ecosystems are vulnerable and facing challenges due to severe anthropogenic as well as climate change (Sarkar et al. 2020). The metadata shows that majority of studies is focused on biodiversity, habitat conservation, and fishery enhancement and recently gained momentum on study of impact of climate change on wetland and fisheries across the globe and assessed the vulnerability of ecosystem using different tools (Sarkar and Borah 2018; Sarkar et al. 2020; Roy et al. 2017b). Substantial change in climate with increasing temperature trend $(0.60 \mathrm{C}$ during last 112 years $)$ and changing pattern and intensity of rainfall have been reported in India. It is projected that extreme climate changes may have profound impact on wetland fisheries (Sarkar et al. 2019). The geographical isolation supports the biodiversity against anthropogenic activities despite being vulnerable to natural disasters (Roy et al. 2017b). Anthropogenic pressure on wetlands are both direct and indirect, which lead to eutrophication, over exploitation, pollution, denitrification, etc. (Roy et al. 2017a; Newton et al. 2020). 


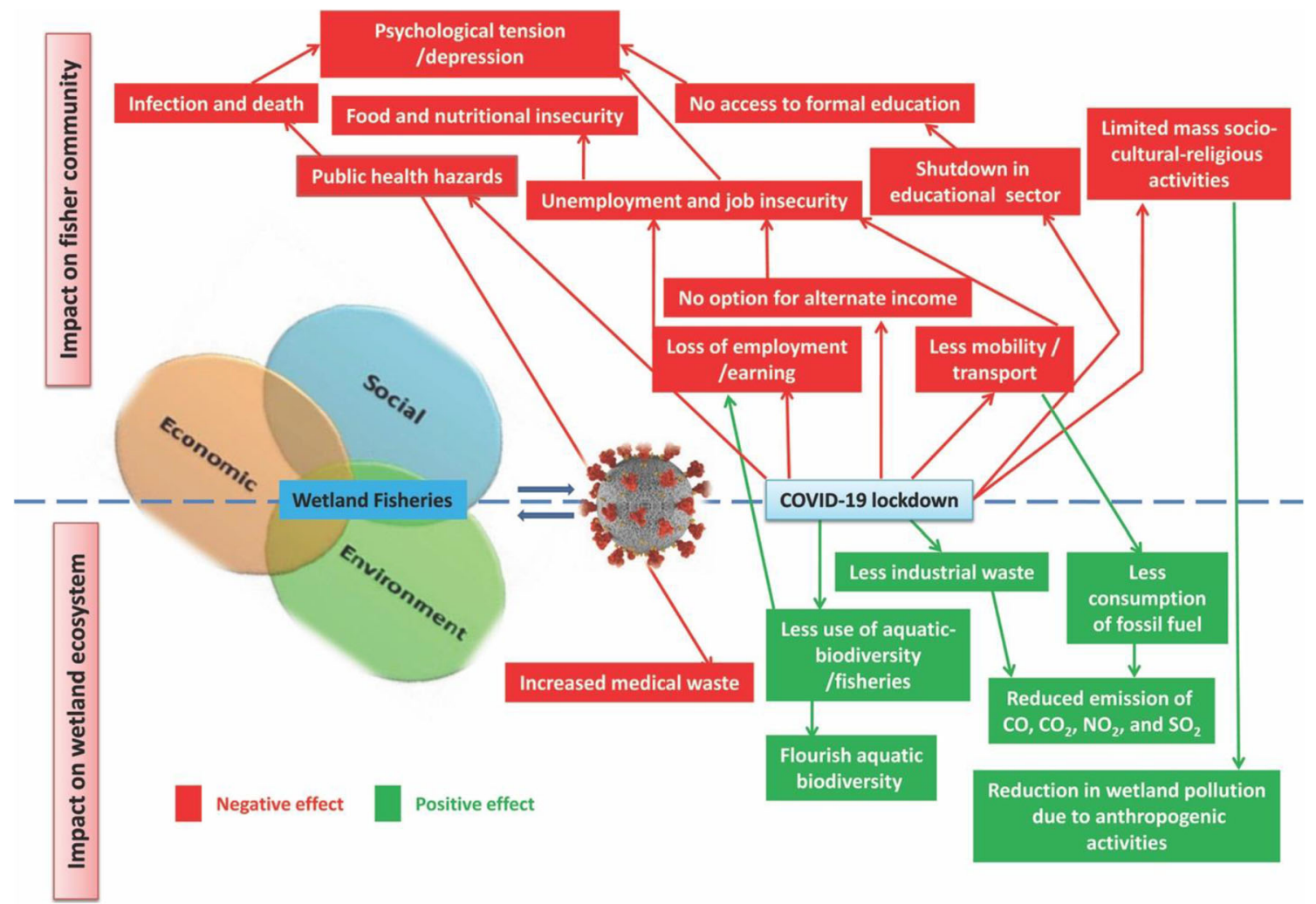

Fig. 5 Impact of COVID-19 on floodplain wetland environment in India

Mainstreaming the ecosystem approach for the management of inland fisheries can fulfill the goal. Lockdown period has positive impact on ecosystem, biodiversity, and "Life below water." Nevertheless, the wetland fishery sector is also relevant to other five SDGs: Goal 1, eradication of poverty; Goal 2, zero hunger; Goal 3, good health and well-being; Goal 8, decent work and economic growth; and Goal 13, climate action.

Inland fisheries have a particularly low carbon footprint in comparison with other food sources (Ainsworth and Cowx 2018), and wetlands are an important carbon sink (Sarkar et al. 2020). Therefore, wetlands have remained vital in global carbon balance and climate change mitigation (Salimi et al. 2021). A positive environmental change in aquatic ecosystem was observed in India after the COVID-19 lockdown and reported in electronic media; however, negative impact was marked on the fisherman community (Fig. 5). Adverse impact was noticed on public health, employment and earnings, transport, alternate income generating option, food and nutritional security, mass socio-cultural-religious activities, etc. Shut down in educational sector hampered the access of learning of the children of fisher families. On the other hand, decrease in wetland pollution was noticed due to less anthropogenic activities, reduced industrial waste, and reduced emission of $\mathrm{CO}, \mathrm{CO}_{2}, \mathrm{NO}_{2}$, and $\mathrm{SO}_{2}$. Less consumption of fossil fuel and less exploitation of aquatic biodiversity and fisheries caused improved water quality and ecosystem health, and it ultimately lead to flourish aquatic biodiversity and recruitment of indigenous fish in the wetlands.

The life of human being is halted and shut off from routine work, fishing, and fishery-related activities due to COVID-19 that have affected the whole world severely during February to April 2020. Although we have not assessed the ecology and water quality during that period, published reports (Kulk et al. 2021: Ali et al. 2021; Chakraborty et al. 2021) showed that the impacts of lockdown are tremendous on reduction of pollution load on the aquatic ecosystem and improved the ecosystem health. It is advisable and very much possible to set guidelines in such a way that fishing practice and environmental policy guideline should mention clearly for releasing type in industrial waste and restriction on use of mechanized/motorized boat in a manner that do not negatively impact the aquatic ecosystem.

\section{Conclusion}

The COVID-19 has created an unprecedented situation as well as destitution for the wetland-based SSF of India. Their livelihoods have been highly impacted, and it has led to an increase in stress, anxiety, and financial insecurity in their daily life. So, a speedy recovery is very much intended, and it could only be possible if cooperation between state fishery department 
and the fishers of respective wetlands shall be encouraged. The state fishery departments and National Fisheries Development Board (NFDB), India, may also come out with need-based relief package for the floodplain wetland fishers on a priority basis. The timely advisories and recommendation can be applicable to the development of national and international wetland fishery guidelines in this pandemic situation. One of the most important learning of this lockdown for authorities is that there is no need to completely stop fishery activities in inland sector. In the future, during the pandemic situations, fishing practices in wetlands may be allowed in calibrated manner within time limits with restrictions to the number of fishers. It is expected that the information generated will help the policy makers in formulating policies and guidelines for inland SSF management in floodplain wetlands in pandemic-like situations.

Acknowledgements The authors are grateful to the Indian Council of Agricultural Research (ICAR) and Director, ICAR-CIFRI, Barrackpore, for providing facilities to carry out the study. We are also thankful to respective state fisheries and the members of the cooperative societies for their cooperation during data collection. The authors also acknowledge constructive suggestions of anonymous reviewers and constructive comments which helped us in strengthening the manuscript.

Author contribution Conceptualization: Basanta Kumar Das. Methodology: Aparna Roy and Ganesh Chandra. Formal analysis and data collection: Suman Kumari. Writing - original draft preparation: Sukanya Som. Writing (review), synthesis of data, and editing: Aparna Roy and Uttam Kumar Sarkar. Data collection: Archan Kanti Das and Arun Pandit. Data support: Birendra Kumar Bhattacharjya. All the authors read and approved the final manuscript.

Funding The research was conducted with the fund support of the ICARCentral Inland Fisheries Research Institute.

Data availability Data will be available based on request.

\section{Declarations}

Ethics approval The submitted manuscript is not submitted in any other journal.

This manuscript does not involve the use of any live animal or human data or tissue. The data were directly obtained from the stakeholders and were used for research.

\section{Consent to participate Not applicable}

Consent for publication The approval for submitting the manuscript was received from the ICAR-Central Inland Fisheries Research Institute.

Competing interests The authors declare no competing interests.

Disclaimer The statements made herein are solely the responsibility of the authors.

\section{References}

Acharya R (2020) Reduced food and diet quality, and need for nutrition services during COVID-19: findings from surveys in Bihar and Uttar Pradesh. Available: https://southasia.ifpri.info/2020/07/09/ $15081 /$

ADB (2020) The economic impact of the COVID-19 outbreak on developing Asia. ADB Briefs 128, Asian Development Bank, Philippines, Mandaluyong

Ainsworth RF, Cowx IG (2018) Validation of FAO inland fisheries catch statistics and replacement of fish with equivalent protein sources. Unpublished report to FAO

Ali PY, Yoshifumi M, Yasuaki H (2021) COVID-19 and surface water quality: improved lake water quality during the lockdown. Sci Total Environ 731:139012,ISSN 0048-9697. https://doi.org/10.1016/j. scitotenv.2020.139012

Aqua International (2020) COVID-19 inflicts a daily loss of Rs 224 crore to India's fishery sector. Aqua International 16

Aura CM, Nyamweya CS, Odoli CO, Owiti H, Njiru JM, Otuo PW, Waithaka E, Malala J (2020) Consequences of calamities and their management: the case of COVID-19 pandemic and flooding on inland capture fisheries in Kenya. J Great Lakes Res 46(6):17671775

Azim Premji University (2020) Covid-19 livelihoods survey: early findings from phone surveys. Azim Premji University, Bangalore

Block ES, Erskine L (2012) Interviewing by telephone: Specific considerations, opportunities, and challenges. Internat J Qualit Methods 11 (4):428-445

Bennett A, Patil P, Kleisner K, Rader D, Virdin J, Basurto X (2018) Contribution of fisheries to food and nutrition security: current knowledge, policy, and research. NI Report.

Bennett R, Singh D, Umarhadi DA, Yunus AP, Misra P, Desai PN, Kouser A, Kurniawan TA, Phanindra K (2021) Impact of COVID19 lockdown on the fisheries sector: a case study from three harbors in Western India. Remote Sens 13:183. https://doi.org/10.3390/ rs 13020183

Briceno-Lagos N, Monfort MC (2020) Why using a gender lens to analyse COVID-19 impacts on the seafood industry? SPC Women Fish Inf Bull 32:4-6

Campbell BL, Rihn AL, Campbell JH (2021) Impact of the Coronavirus pandemic on plant purchasing in Southeastern United States. Agribusiness 37(1):160-170

Ceballos F, Kannan S, Kramer B (2020) Impacts of a national lockdown on smallholder farmers' income and food security: empirical evidence from two states in India. World Dev 136:105069

Chakraborty B, Roy S, Bera A, Adhikary PP, Bera B, Sengupta D, Bhunia GS, Shit PK (2021) Eco-restoration of river water quality during COVID-19 lockdown in the industrial belt of eastern India. Environ Sci Pollut Res 28:25514-25528. https://doi.org/10.1007/ s11356-021-12461-4

Chandra G (2009) Fisher management regimes and fisheries governance in floodplain wetland of Assam. Available at SSRN: https://ssrn. com/abstract $=2086483$

Chandra G (2010) Impact of adoption of pen culture technology on wellbeing of fishers of Haribhanga Wetland in Assam. Indian Res J Ext Educn 10(2):61-65

Chandra G (2011) Management Regimes and Institutional Arrangement in Floodplain Wetlands Fisheries of Assam: An Evaluation. Indian J Exten Educ 47(1-2):27-33

Chandra G, Bhattacharjya U (2016) Institutions and governance in fisheries of Indian Brahmaputra River Basin. J Agric Search 3(1):51-56

Chandra G, Das BK (2019) Governance and institutional arrangement in floodplain wetlands fisheries of India: comparative study of Assam and Bihar. J Inland Fish Soc India 51(1):82-90 
Chandra G, Ekka A (2015) Tenurial rights and institutional arrangement in floodplain wetland fisheries of Bihar. https://doi.org/10.13140/ RG.2.1.1897.9283

Chandra G, Sharma AP, Sahu SK (2013) Impact of pen-culture technology on fish productivity of floodplain wetlands in Asom. Indian J Anim Sci 83(2):209-215

Coll M, Ortega-Cerdà Y, Mascarell-Rocher Y (2021) Ecological and economic effects of COVID-19 in marine fisheries from the Northwestern Mediterranean Sea. Biol Conserv 255:108997. https://doi.org/10.1016/j.biocon.2021.108997

Cooper CD, Kurland NB (2002) Telecommuting, professional isolation, and employee development in public and private organizations. J Organizational Behavior 23:511-532

Das BK, Chandra G, Kumari S, Meena DK, Kaushlesh SK, Baitha R, Trivedi RK (2019) Roadmap for fisheries development in mauns and chaurs of Bihar. Policy Paper 6. Central Inland Fisheries Research Institute, Kolkata, p 30

DebRoy P, Das BK, Parida PK, Roy A, Chakraborty S (2021) Economic injustice in small-scale wetland Fisheries in West Bengal, India. In: Kerezi V, Chuenpagdee R (eds) Blue Justice For Small-Scale Fisheries: A Global Scan, vol 2. TBTI Global Publication Series, St. John's

Dhakade M (2020) COVID -19 impact on the livelihood of small and marginal farmers. Business of Agriculture 6(1):14-15

Eriksson H, Ride A, Boso DN, Sukulu M, Batalofo M, Siota F, Gomese C (2020) Changes and adaptations in village food systems in Solomon islands: a rapid appraisal during the early stages of the COVID-19 pandemic. WorldFish, Penang

Everard M, Johnston P, Santillo D, Staddon C (2020) The role of ecosystems in mitigation and management of Covid-19 and other zoonoses. Environ Sci Pol 111:7-17. https://doi.org/10.1016/j.envsci. 2020.05.017

FAO (2000) FAO Yearbook. Fishery statistics, Capture Production for 1998, vol 86/1. FAO, Rome

FAO (2015) Voluntary guidelines for securing sustainable small-scale fisheries in the context of food security and poverty eradication. Food and Agriculture Organization of the United Nations, Rome

FAO (2020) How is COVID-19 affecting the fisheries and aquaculture food systems. FAO, Rome. https://doi.org/10.4060/ca8637en

FAO FishStatJ (2019) FAO Fish Stat J database: 2019 dataset. http:// www.fao.org/fishery/statistics/software/fishstatj/en. Accessed July 2019

Funge-Smith S (2018) Review of the state of the world fishery resources: inland fisheries. In: FAO Fisheries and Aquaculture Circular. Food and Agriculture Organization of the United Nations, Rome

Funge-Smith S, Bennett A (2019) A fresh look at inland fisheries and their role in food security and livelihoods. Fish Fish 20:1176-1195. https://oi.org/10.1111/faf.12403

Gretchen LS, Abigail JL, Benjamin SL, Simon FS, John VJ, Samuel JS (2020) COVID-19 pandemic impacts on global inland fisheries. Proc Natl Acad Sci 117(47):29419-29421. https://doi.org/10.1073/ pnas.2014016117

Hakovirta M, Denuwara N (2020) Wang How COVID-19 redefines the concept of sustainability. Sustainability 12:3727. https://doi.org/10. 3390/su12093727

Handbook on Fisheries Statistics (2014) Government of India, Ministry of Agriculture, Department of Animal Husbandry, Dairying \& Fisheries, Krishi Bhavan, New Delhi.p.12

Handbook on Fisheries Statistics (2018) Government of India, Ministry of Agriculture, Department of Animal Husbandry, Dairying \& Fisheries, Krishi Bhavan, New Delhi.p.22

Harris J, Depenbusch L, Pal AA, Nair RM, Ramasamy S (2020) Food system disruption: initial livelihood and dietary effects of COVID19 on vegetable producers in India. Food Secur 12:841-851

Hassan MA, Das BK, Mishal P, Karnatak G, Baitha R, Chandra G, Kumari S, Liamthuamluaia L, Swain HS (2019) Stride in fish yield through participatory Technological Interventions in Oxbow lakes of Bihar. Folder. ICAR-CIFRI, Barrackpore, Kolkata.

IFPRI (2021) 2021 Global Food Policy Report: Transforming Food Systems after COVID-19. International Food Policy Research Institute, Washington, DC. https://doi.org/10.2499/9780896293991

Ilies R, Schwind KM, Wagner DT, Johnson MD, DeRue DS, Ilgen DR (2007) When can employees have a family life? The effects of daily workload and affect on work-family conflict and social behaviors at home. J Appl Psychol 92(5):1368-1379

Jaacks LM, Veluguri D, Serupally R, Roy A, Prabhakaran P, Ramanjaneyulu GV (2021) Impact of the COVID-19 pandemic on agricultural production, livelihoods, and food security in India: baseline results of a phone survey. Food Sec. https://doi.org/10.1007/ s12571-021-01164-w

Jena J, George G (2018) Small-scale fisheries in India: an appraisal. In Giri S (ed) Small-scale Fisheries in South Asia. South Asian Association for Regional Cooperation Agriculture Centre, Bangladesh, pp 15-41

Kar D (2019) Wetlands and their fish diversity in Assam (India). Transylv Rev Syst Ecol Res 21(3):47-94

Kulk G, George G, Abdulaziz A, Menon N, Theenathayalan V, Jayaram C, Brewin RJW, Sathyendranath S (2021) Effect of reduced anthropogenic activities on water quality in Lake Vembanad, India. Remote Sens 13:1631. https://doi.org/10.3390/rs13091631

Laborde DD, Martin W, Vos R (2020) Impacts of COVID-19 on global poverty, food security and diets. IFPRI Discussion Paper 1993. Washington: International Food Policy Research Institute (IFPRI). https://doi.org/10.2499/p15738coll2.134229

Love D, Allison EH, Asche F, Belton B, Cottrell RS, Froehlich HE, Gephart JA, Hicks C, Little DC, Nussbaumer EM, DaSilva PP, Poulain F, Rubio A, Stoll JS, Tlusty MF, ThorneLyman AL, Troell M, Zhang W (2021) Emerging COVID-19 impacts, responses, and lessons for building resilience in the seafood system. Glob Food Secur 28:100494. https://doi.org/10.1016/j.gfs.2021. 100494

Mahendra DS (2020) Addressing COVID-19 impacts on agriculture, food security, and livelihoods in India. In: Swinnen J, McDermott J (eds) COVID-19 and global food security. Part One: Food security, poverty, and inequality, chapter 7, pp 33-35. Washington: International Food Policy Research Institute (IFPRI). https://doi. org/10.2499/p15738coll2.133762 07

Mangubhai S, Nand Y, Reddy C, Jagdish A (2021) Politics of vulnerability: impacts of COVID-19 and Cyclone Harold on Indo-Fijians engaged in small scale fisheries. Environ Sci Policy 120:195-203

Newton A, Icely J, Cristina S, Perillo GME, Turner RE, Ashan D, Cragg S, Luo Y, Tu C, Li Y, Zhang H, Ramesh R, Forbes DL, Solidoro C, Béjaoui B, Gao S, Pastres R, Kelsey H, Taillie D, Nhan N, Brito AC, de Lima R, Kuenzer C (2020) Anthropogenic, direct pressures on coastal wetlands. Front Ecol Evol 8:144. https://doi.org/10.3389/ fevo.2020.00144

Polkinghorne DE (2005) Language and meaning: data collection in qualitative research. J Couns Psychol 52(2):137-145

Roy SD, Krishnan P, Patro S, George G, Velmurugan A, Sankar RK, Ramachandran P (2017a) Wetlands of small island nations in South Asia vis-a-vis the mainland and island groups in India: status and conservation strategies. In: BAK P (ed) Wetland science, perspective from South Asia, pp 31-48.

Roy SD, Krishnan P, Velmurugan A, Anand A, George G, Sankar RK, Swarnam TP (2017b) Wetlands of tropical islands under changing climate: a case from Nicobar group of islands, India. In: BAK P (ed) Wetland science, perspective from South Asia, pp 205-224.

Salimi S, Almuktar SAAAN, Miklas S (2021) Impact of climate change on wetland ecosystems: a critical review of experimental wetlands. J Environ Manag 286:112160, ISSN 0301-4797. https://doi.org/10. 1016/j.jenvman.2021.112160 
Sarkar UK, Borah BC (2018) Flood plain wetland fisheries of India: with special reference to impact of climate change. Wetl Ecol Manag 26 (1):1-15. https://doi.org/10.1007/s11273-017-9559-6

Sarkar SD, Gogoi P, Sarkar UK, Mishal P (2019) Trophic state index to assess aquatic ecosystem health. Indian Farm 69(3):63-66

Sarkar UK, Mishal P, Borah S, Karnatak G, Chandra G, Kumari S, Meena DK, Debnath D, Yengkokpam S, Das P, DebRoy P (2020) Status, potential, prospects, and issues of floodplain wetland fisheries in India: synthesis and review for sustainable management. Rev Fish Sci Aquac 29:1-32. https://doi.org/10.1080/23308249.2020. 1779650

Schweitzer L, Duxbury L (2006) Benchmarking the use of telework arrangements in Canada. Can J Adm Sci 23(2):105-117

Smith H, Basurto X (2019) Defining small-scale fisheries and examining the role of science in shaping perceptions of who and what counts: a systematic review. Front Mar Sci 6(236). https://doi.org/10.3389/ fmars.2019.00236

Steenbergen DJ, Neihapi PT, Koran D, Sami A, Malverus V, Ephraim R (2020) COVID-19 restrictions amidst cyclones and volcanoes: a rapid assessment of early impacts on livelihoods and food security in coastal communities in Vanuatu. Mar Policy 121:104199. https:// doi.org/10.1016/j.marpol.2020.104199

Stokes et al (2020) COVID-19 pandemic impacts on global inland fisheries. https://doi.org/10.1073/pnas.2014016117.

Sugunan VV, Bhattacharjya BK (2000) Ecology and fisheries of beels in Assam. ICAR-CIFRI, Barrackpore, $\mathrm{p} 65$
Sugunan VV, Sinha M (1997) Fisheries enhancement of small reservoirs and floodplain lakes in India. ICAR-CIFRI, Kolkata, p 252

Sugunan VV, Sinha M (2001) Sustainable capture and culture based fisheries in fresh waters of India. In: Pandian TJ (ed) Sustainable Indian fisheries. National Academy of Agricultural Sciences, New Delhi, pp 43-70

Sugunan VV, Jha BC, Das MK (2002) Culture based fisheries for inland fisheries development. Bulletin No. 113. ICAR-CIFRI, Barrackpore, p 197

Wang C, Horby PW, Hayden FG, Gao GF (2020) A novel coronavirus outbreak of global health concern. Lancet 395:470-473. https://doi. org/10.1016/S0140-6736(20)30185-9

WHO (2020) Novel Coronavirus (2019-nCoV) Situation Report - 121 January 2020

World Bank (2012) Hidden harvest: the global contribution of capture fisheries. Worldbank; WorldFish; FAO, Washington, DC

Zhang C, Wen L, Wang Y, Liu C, Zhou Y, Lei G (2020) Can constructed wetlands be wildlife refuges? A review of their potential biodiversity conservation value. Sustainability 12:1442. https://doi.org/10.3390/ su12041442

Publisher's note Springer Nature remains neutral with regard to jurisdictional claims in published maps and institutional affiliations. 